\title{
Comment
}

\section{When Victims Happen To Be Black}

\author{
Stephen L. Carter†
}

I.

Shortly after a New York jury acquitted Bernhard Goetz of charges that he had attempted murder by rising angrily from his subway bench and shooting down four youths who were, in the polite euphemism of the street, hassling him for money, a syndicated cartoonist was inspired to draw what was intended to be the post-Goetz subway car. The imagery was at once stark and homely: two elderly women seated side-by-side in a car empty of other passengers, a screwdriver lying nearby, and outside, a crowd of people, eyes widened with fear, running away from the car. One of the women says to the other: "Heavens! . . I was just reaching for my lipstick." "1

Such evocation in a simple cartoon! For the artist managed, with those seven words, to capture the shuddering tensions apparent in public reactions to the Goetz incident and the verdict in his trial, and much more besides. Mr. Goetz's public-those who declared him a hero from the first-can find in this cartoon a portrait of salvation of a sort. The people fleeing are thugs and toughs, the anonymous yet ubiquitous individuals who frequent New York's subway trains and cast terror with a glance. Now they must think twice about their victims. If those who are frightened can defend themselves with violence, then every honest and angry subway rider is a threat to those who have made the subway a violent place. Even intimidating a little old lady no longer promises gain without

- Stephen L. Carter

$\dagger$ Professor of Law, Yale University. An earlier version of this essay was presented at a Yale Law School Faculty Workshop. In addition to the questions raised there, I have had the special benefit of suggestions and criticisms, on either the essay or the ideas behind it, from Enola Aird, Akhil Amar, Lea Brilmayer, Harlon Dalton, Drew Days, Izhak Englard, Owen Fiss, George Jones, Randall Kennedy, Martha Minow, Barry Nalebuff, Roberta Romano, Jeff Strnad, and Ruth Wedgwood. Karen Porter rendered splendid research assistance.

1. Summers, Orlando Sentinel, 1987, reprinted in NewsweEk, June 29, 1987, at 19. 
risk, for when she reaches into her handbag, what comes out might as easily be a handgun as a change purse. Perhaps the odds are that she will turn over her paltry bankroll, as the hasslers hope, but the possibility that she will attack instead forces the criminals to reevaluate their plan. She might use force, even deadly force, to protect herself. Perhaps discretion is the better part of terror, and the young toughs who are thinking all of this through might do best not to be in the car when her hand emerges.

No sophisticated theory of law or politics is needed to read this story in the cartoon and, by extension, in the Goetz case itself. What is necessary is an instinct-an instinct about the nature of victimhood. Victimhood has no objective measure and, indeed, the label has no significance outside the context in which it is applied. Like so much of what is needed to make sense of the world, the concept of victimhood is socially constructed. ${ }^{2}$ To speak of a true or a false claim of victimhood makes no sense, unless one first specifies the social context in which the claim is made.

There is no tragedy in the conclusion that victimhood is socially constructed. Potential tragedy lurks, however, in the way we as a society construct it. By using the Goetz affair and a handful of other cases as examples, it is possible to learn a great deal, little of it pleasant, about the way we think and talk about victimhood and the way we think and talk about race and the way we think but do not talk about the relationship between the two. The meaning of victimhood in our society is constructed by a dominant culture that often displays difficulty conceiving that important harms can come in varieties unlikely to afflict its members. ${ }^{3}$ This construction of victimhood, in American law, American politics, and American popular culture, makes virtually inevitable-perhaps even necessary-the vision of Bernhard Goetz as heroic victim, and, consequently, the image of the black youths on the train as victimizers.

The dominant culture's construction of victimhood awards the status of victim to someone who loses something-property, physical safety-because of the predation of someone else. Victimization, then, is the result of concrete, individual acts by identifiable transgressors. To give a name to the bundle of instincts underlying this social construction of victimhood, we might call it bilateral individualism, because it invents a reality in which the only victims are those who have suffered at the hands of transgressors, and in which any sanctions should be directed toward deterring or punishing those transgressors. ${ }^{4}$ To put a theoretical point on

2. See generally P. Berger \& T. Luckman, The Social Construction of Reality: A Treatise In the Sociology of KNowledge (1967).

3. In this sense, the social construction of victimhood rests in large measure on the problem that some theorists would call "difference"-here, the inability of the dominant culture to understand as victimhood anything not likely to happen to its members. Cf. Minow, The Supreme Court, 1986 Term-Foreword: Justice Engendered, 101 HARv. L. REv. 10 (1987) (outlining how "difference" makes it difficult for dominant groups to appreciate legal claims of "others").

4. For a general discussion of the position taken by those espousing philosophies much like bilat- 
this bundle of instincts, a principal reason for entering into civil society-perhaps the only reason-is to facilitate the punishment of these transgressors. The government's proper role, then, is to establish a police force and courts to deter those who would trespass on the freedom of others. To one who accepts this vision, a world like ours, one in which so many violent crimes occur and go unpunished by the state, must seem a world in which the forces of order have lost control, a world tumbling back toward a pre-Leviathan state of nature, toward a life that is indeed solitary, poor, nasty, brutish, and short. If the government cannot or will not protect the people, then the social compact is rent asunder, and people have to protect themselves against the stream of evil pouring through.

The central vision, then, is one of government failure. People are afraid of crime and are afraid of becoming victims. They want to strike back at someone to liberate themselves from their fear. Bilateral individualism, if it is to make the constructed reality acceptable, must rationalize that need to strike out. Assuming that the fear of crime is not itself irrational, bilateral individualism can rationalize the need to strike back only by insisting that there are potential criminals-transgressors that the government is failing to stop. These transgressors are real, individual people, and other individuals have the right to turn their assaults aside. The bilateral individualist reality must have these potential transgressors, for without them, there are no potential victims. If the transgressors really exist, as the theory says they must, then there is hope as long as they can be ferreted out. This public is as ready, in its fear, to strike out at these potential victimizers for what harm they might do as it is to strike back at them after the harm is done. But the decision to strike back must always be a rational one, directed at the proper transgressor, or the bilateral individualist construction of victimhood fails to justify the striking.

The abstract theory intersects popular culture only when concrete examples become available. Stories like Bernhard Goetz's become true because the popular culture demands their truth. A public fearful of criminal assault recognizes the pattern of victimization presented in the Goetz case, and his story becomes true because of the way it mirrors the deepest anxieties of a part of that public, while unleashing the fantasy in which striking back dissolves the fear. "He's like us and we would do like him," might be the way the point is reasoned. And if people identify with him, even envy him a little, he becomes a kind of folk hero.

As folk hero, however, Bernhard Goetz is ultimately a disturbing figure. Even Mr. Goetz's defense painted him as something less than heroic. The defense was weakest on the issue of why he fired a second shot at a

eral individualism and a critique of its problems, see J. FeInBerg, Harm to Others (1984). The term bilateral individualism is useful because it emphasizes the notion of individual responsibility based on the bilateral relationship-what one individual does to another. 
helpless Darrel Cabey, now suffering paralysis and possible brain damage. Barry Slotnick, the defense attorney, offered a version of events in which, once the gun was drawn, Mr. Goetz's self-preserving instinct took command. ${ }^{5}$ Matters moved so quickly that his instinct would not let him stop until he was certain that none of those who had frightened him could do him any harm. He fired and kept on firing. In other words, his mind was not in control; he did not know what he was doing.

The jury plainly accepted the rapid-fire theory as a reasonable explanation of Mr. Goetz's behavior. Mr. Goetz's public, however, the millions who apparently believe that they would have done precisely what he did and that the punks he shot got what they deserved, does not base its enthusiasm on the understanding that he was out of control. On the contrary, the notion that he was in control is part of the appeal of his situation. To his public, Mr. Goetz was cool and calculating, showing the courage that millions of others would wish for themselves. He was not out of control, he was helping to wrest control-control of the subway, control of the streets, control of the city-from the vicious thugs who have taken over. For a public desperate to see transgressors punished, a public desperate to admire him as punisher, the image of Mr. Goetz as heroic model of restrained anger is vital. The alternative would crush every illusion of the rational use of force: People who carry loaded guns around and then lose control of what they do with them are rarely thought eligible for Mount Rushmore.

The rush by a part of the public to transform Bernhard Goetz from panicked victim to heroic avenger is especially troubling because, in a society that has suffered as ours has, the search for heroes is one that must be conducted with some care. There are lines that cannot be crossed, even in the search for heroes, and a celebration of a white man for shooting four black ones falls very close to one of them. Thus, a public conscious of the racial symbolism of the incident, in order to hold up Bernhard Goetz as a shining example of self-help in the face of government incompetence, must first set up a rear guard which goes something like this: Victims and criminals come in all colors, and the demands of justice should be the same for all of them. Mr. Goetz was attacked. His white skin is a coincidence. The young men he shot were his attackers. Their black skins are also a coincidence. A black man would have had the same right to defend himself against white punks as this white man had to defend himself

5. See Johnson, Goetz's Taped Accounts Wrong, Lawyer Says, N.Y. Times, June 11, 1987, at B1, col. 5, B4, col. 4 (Slotnick's argument that Goetz fired too quickly to stop and calculate); Johnson, Goetz Didn't Shoot Youths in Back As They Ran Away, Witness Says, N.Y. Times, June 2, 1987, at B5, col. 5 (defense expert states that victims were shot in "rapid succession" and had no time to flee). Mr. Goetz, in his videotaped statement to the police following his arrest, stated: "If I had more bullets, I would have shot them all again and again. My problem was I ran out of bullets. . . ." Hornblower, Jury Exonerates Goetz in 4 Subway Shootings, Wash. Post, June 17, 1987, at A1, col. 5, A15, col. 2 . 
against black ones. ${ }^{6}$ If the rear guard is sufficiently powerful, the bilateral individualist construction of reality has nothing to do with race, in which event the Goetz case has nothing to do with race, in which event the public support for Mr. Goetz has nothing to do with race.

The rear guard action succeeds up to a point, because criticizing the jury's verdict without sitting through the trial seems quite silly. Maybe Mr. Goetz deserved his acquittal; maybe he read the glassy stares and body language correctly; maybe he was moments away from a severe beating, even a fatal one. But the rear guard action is not quite sufficient to write racial consciousness out of the decision of a part of the public to lionize Bernhard Goetz as Everyman. The tragedy of the Goetz case is that a public barely aware of the facts was rooting for him to get away with it. The tragedy is that a public eager to identify transgressors in advance decided from the start that Mr. Goetz was a hero and that his black victims deserved what they got.

The simple point is that no one who was not in the subway car could know with any certainty whether $\mathrm{Mr}$. Goetz needed to use the force that he did. Until the case came to trial, Mr. Goetz's fans had little more to go on than Mr. Goetz's version of the facts-the fear, the rage, the impending assault-and the version offered by some of those he shot. In their version, they asked him for money and he started to shoot, continuing his attack even when there was no further threat. Maybe the youths were lying; certainly some members of the jury were later quoted as calling the testimony of the young men incredible. ${ }^{7}$ But at trial, the prosecution and defense put on quite a battle of experts, discussing angles of entry wounds and distance from target and positions of fall, to try to prove who was standing or sitting or lying where as the shots were fired. The result of the expert testimony was a confusing mush, certainly not enough to prove beyond a reasonable doubt that all was as the prosecutor claimed. ${ }^{8}$ That alone might justify the acquittal, not because Bernhard Goetz's story was true, but because the prosecutor had failed to prove it false. Mr. Goetz's public accepted his version of the story from the beginning. The central message of hero-worship remains the same: "In his shoes, we would have done what he did. We know that what he did was right. We have all the facts we need to make up our minds."

In the popular imagination, the facts were clear. Consider, for example, who it was that Mr. Goetz actually shot. In the public mind, these were not good kids, but violent, dangerous street punks. (Perhaps only good

\footnotetext{
6. In one juror's words, "It didn't matter if he was a white man or black man." In another's, "Crime doesn't know a color." Id.

7. Pitt, Goetz Jurors Found Both Sides' Evidence Difficult to Accept, N.Y. Times, June 17, 1987, at $\mathrm{A} 1, \mathrm{col} .6$.

8. See, e.g., N.Y. Times, June 6, 1987, at A32, col. 6 (recounting confusion caused by ane expert's testimony); Johnson, supra note 5 (expert disputing previous expert's testimony); Pitt, supra note 7 (juror says prosecution expert's testimony was inconsistent).
} 
kids can be bona fide victims.) Look at "victim" James Ramseur, possessed of explosive anger and open contempt for authority, for justice, for order, who verbally abused judge, prosecutor, and defense attorney in open court. ${ }^{\theta}$ Look at the angry, primitive set of his features, his bulky aggressiveness, listen to his snarl; then look at Bernhard Goetz, pale, slight, unassuming, and imagine the confrontation. How much more threatening must James Ramseur and his colleagues have appeared in the subway train? How much, indeed? Leather jackets, dark trousers, and scowls on their dark, angry faces-who could fail to see the threat? Imagine Bernhard Goetz's apprehension. Then his terror. Then his memories of past assaults. Then his rage.

Berhnard Goetz's admirers endorsed this view with enthusiasm and vehemence long before the trial ever took place; they took a close look at the four wounded youths and decided that Mr. Goetz was telling the truth. Yes, obviously they were threatening him; anyone could see that. Yes, obviously he used the amount of force needed to resist the threat; anyone would have used the same amount of force, which, translated, is the amount of force his attackers deserved. And once one accepts this image of the pale, victimized Bernhard Goetz and the dark, angry attackers, the trial is almost beside the point, its outcome easy to predict, and with specificity: Hunting animals without a license is not the same offense as attempted murder.

The public had yet another fact in its possession, a fact that helps make sense of the shift from unruly youths to unwanted animals. The public knew the skin colors of everyone involved. If one knows in advance that black people tend to be transgressors and white people tend to be victims, it is fairly simple to sort out who's who once the participants are identified by race. The short of it is that the story of the subway car as perceived by Mr. Goetz's public-the choice of transgressor, the choice of victim-might have been starkly different had Mr. Goetz been black and the others white, and had Mr. Goetz cried "self-defense" while the others insisted that when he pulled the gun, they had been minding their own business. For in that event, a public with no real knowledge of the facts other than the stories told by the participants and the skin colors of the

9. Mr. Ramseur, when first called as a witness, refused to place his hand on the Bible or be sworn. Johnson, Youth Shot by Goetz Balks at Testifying; Is Held In Contempt, N.Y. Times, May 6, 1987 , at A1, col. 1. When he finally agreed to testify, he scowled at the lawyers, shouted at the judge, and directed profanity at both. Johnson, Youth Shot in Subway Says He Didn't Approach Goetz, N.Y. Times, May 20, 1987, at B3, col. 5; Johnson, Witness Refueses to Answer At Goetz Trial and Is Cited, N.Y. Times, May 21, 1987, at B3, col. 5. At one point in his testimony, Mr. Ramseur removed his shoe and scratched his foot. Barry Slotnick was later quoted as insisting that Mr. Ramseur was about to throw the shoe and that a court officer blocked the attempt. Johnson, Reporter's Notebook: Vagaries of the Goetz Trial, N.Y. Times, May 24, 1987, at A26, col. 1. Court officers and eyewitnesses denied Mr. Slotnick's claims. Id. But in a manner entirely consistent with the public's approach to the trial, the story that Mr. Ramseur was about to throw his shoe has become widely accepted. 
shooter and his victims would not have raced at once to Mr. Goetz's defense. But his victims happened to be black, and the rush was on.

Against this background, consider once more the cartoon that opened the essay, this time from the point of view of Mr. Goetz's critics, the ones who have condemned the verdict as opening the hunting season on young black men. Now the people fleeing the car are frightened innocents, victims themselves, probably black or brown, who can no longer be certain which gesture of impatience or annoyance someone else will take as a threat, who are now loathe to ask directions or change of a dollar for fear of a fatal misinterpretation. The elderly women left alone in the car are in this vision unwitting purveyors of further tragedy. Now the symbolism becomes more ironic: Thinking themselves potential victims, the women are unaware of their potential to terrorize other potential victims. They are aging, they are women, they are white-a confluence of factors that probably increases their own fear of assault. And because in society's eyes they are the archetypal victims, were they to shoot and to testify to their fear, their story would be readily believed; the tale told by their tormenters would surely be doubted. So once the trembling hand slips into the handbag, those whose color and countenances make them look more like the hasslers than the hassled have every reason to choose flight.

These law-abiding people of color who might feel obliged to flee the subway car are not victims in the bilateral individualist sense, for there are no transgressors angrily forcing them out of the subway car. Yet if they nevertheless choose flight, it does no good to tell them that they are not victims because there are no transgressors who might be punished for causing their fear. The dominant culture is unable to rationalize that fear within its vision of victimhood, but for the frightened, fear is itself a truth. Because the dominant culture constructs victimhood in a way that denies this truth, those who see in the lionization of Bernhard Goetz a reason for terror, rather than a cause for celebration, might offer another perspective on what should count as victimhood.

This second construction of victimhood would charge that the dominant conception of victimhood ignores the nation's racially oppressive past and its racially charged present. Now victimhood becomes a matter of the sweep of history, not the actions of individual transgressors, and the government's role is not to punish transgressors but to alleviate the suffering of the victims. The victims in this theory of racial oppression are black people generally, and poor black people in particular. On this view, black people are victims not because any individual has done harm to any other individual, but because the society's history and structure have combined to make of them an apparently permanent underclass, deprived of their fair share of wealth, education, health care, and the like.

In this vision of victimhood, the criminal behavior of so many black 
males $^{10}$ is itself a mark of victimhood, a victimhood virtually determined from birth. The problem, it is said, is a racist society, one that has relegated its inner-city youth of color to the status of members of a permanent underclass. Violence-especially violence directed externally, at white people and property (symbols of the oppression!), but also violence that is, in the argot, "black-on-black"-is a statement of frustration. Remove the sources of the frustration-the racism, the "structural" unemployment, the inadequate education-and you eliminate much of the violence.

This second theory, despite some shortcomings, has the virtue of recognizing the fact of racial oppression in American history and of explaining what bilateral individualism cannot: the vague but firm conviction held by so many people of color that they are victims every day of their lives. Bilateral individualism finds that conviction incomprehensible. To an adherent of the dominant construction of victimhood viewing the moral landscape in the years following the murder of Martin Luther King, Jr., and the subsequent collapse of the non-violent civil rights movement, Kingman Brewster's expressed doubts on whether a member of the Black Panther Party could receive a fair trial in the United States or Angela Davis's rigid insistence that all black people convicted of crimes in the United States are political prisoners must have seemed simply crazy.

But under an approach accepting racial oppression as a brutal and lingering fact, the shared victimhood of black people becomes a possibility. So in the Goetz trial, the particular course of events that led to the shooting in the subway car becomes less important than both the social conditions that led to the tragedy and what the aftermath demonstrates about American society: The young black men who hassled Bernhard Goetz were already victims when he shot them, and his ability to fire away with impunity is simply confirmation of their status. ${ }^{11}$ On this view, there would have been no easy acquittal had the man with the gun been black, the men lying bloodied and insensate on the floor white.

Yet the conclusion that the hasslers were victims before they were shot down is in an important sense morally bizarre. It challenges what is strongest in the dominant bilateral individualist world view: the fundamental notion that people are to be held responsible for their own actions. One may concede that the actions of a statistical mass have complex causes, and yet condemn and punish individuals for the actions themselves. Individuals possess a degree of free will, and the pathology of the underclass, no matter how powerful or complex, does not invariably, or

10. In 1985, fully one-third of single offenders who committed violent crimes were identified by the victims as black. Bureau of Justice Statistics, U.S. Departanent of Justice, Criminal Victimization IN THE UNITED STATES, 1985, at 37-38 (1987). In 1986, one-half of those under the age of 18 who were arrested for violent crimes in urban areas were black. BUREAU OF JUSTICE Statistics, U.S. Department of Justice, Uniform Crime Report, 1986, at 17 (1987).

11. See L. Rubin, Quiet Rage: Bernie Goetz in a Time of Madness (1986) (Goetz case as metaphor of violence caused by social injustice). 
even usually, create criminals. The trouble with too much understanding is that it leads to sympathy. The trouble with too much sympathy is that it leads to forgiveness. Hitler was not evil, just insane. At the end of the line is a heap of rubbish. Compassion ought not lead to suspension of judgment. Some people do bad things because they choose to. ${ }^{12}$

But even though the construction of victimhood as the product of racial oppression can lead to moral absurdity, it would be a mistake to dismiss it altogether. The response that some bad things are done by choice provides at best for the culpability (and, by extension, the punishability) of those who do the bad things. It does not provide an explanation of why Bernhard Goetz, himself, was dubbed a hero or the youths he shot the transgressors.

Of course, had the victims-Mr. Goetz's victims-been young white men in business suits, carrying briefcases, and had Mr. Goetz himself been a stocky black man in blue jeans and leather jacket, a substantial portion of the public might nevertheless have rallied to his defense before trial, just as Mr. Goetz's defenders insist. One cannot sensibly add, however, "assuming the other facts to be the same." The other facts could not possibly be the same were the skin colors reversed, for America, however noble its aspirations, sees skin color. Blackness is noticed, and it can threaten simply by appearing unexpectedly, in a wealthy white suburb in the middle of the day, on a darkened sidewalk in the middle of the night, on the other side of the peephole in the door when no one is expected. Thus when Mr. Slotnick, the defense attorney, kept inviting the jury (and, by extension, the public) to imagine the atmosphere in the subway car, he conjured, whether he planned to or not, an image of innocent whiteness surrounded by threatening blackness. ${ }^{13}$ Those who endorse a vision of victimhood resting on the fact of racial oppression would here win a vital point: Emotive power would be lost were one to conjure instead an image of "innocent blackness" surrounded by "threatening whiteness."

The simplest truth is that the response of a large part of the public to the events in the subway car was very likely inevitable: The image of Bernhard Goetz as a transgressor cannot match the constructed reality in a world in which race makes a difference, and as a consequence, $\mathrm{Mr}$. Goetz's public simply refused to take it seriously. This closer examination of the Goetz affair suggests a painful lesson lurking in the shadowy reality of our dominant means of deciding who is entitled to be called "victim" and who deserves the epithet "transgressor." For no matter how attractive

12. Cf. Loury, "Matters of color"-blacks and the constitutional order, The Public INTEREsT, Winter 1987, at 109 (arguing that using shared victimhood to excuse individual culpability makes individual achievement unlikely).

13. That some members of the jury and many of Bernhard Goetz's supporters were black does not alter the starkness of the imagery. The fear of violent crime does not respect the skin color of the fearful; there is no reason to think that the rationalization of that fear should be more choosy. 
the vision of victims as people harmed by concrete transgressors may be in the abstract, when it is used as the lens to focus the decision on who is a victim and who is not in this society, its concrete effect may often be a rush to call black people transgressors and white people their victims. Outside of the most egregious examples of overt racial oppression, a construction of victimhood that cannot acknowledge the possibility of victimizations without transgressors is bound to reject the reality perceived by so many victims who happen to be black.

\section{II.}

When victimhood becomes a prediction of the future rather than a description of the past, criteria are needed to determine the likely victims. Since the dominant culture defines victimization only in relation to individual transgressions, determining the likely victims means determining the likely transgressors. The public text of national morality, however, does not permit the use of just any criteria. America's history, and the world's, have taught us all to resist-in public dialogue, at least-any suggestion that racial criteria should play a part in the process of prediction. And if public symbols teach private morality, then this popular condemnation is plainly a good thing. It is not, however, the end of the tale.

Racial stereotyping-ascribing to all members of a group characteristics thought to be possessed by some-is simply not an odd and rare facet of life in the United States. Those with the wealth to do so are willing to pay premiums for the privilege of living in neighborhoods that are, by accident or by design, relatively free of black neighbors. Good liberals who would react with horror should the police single out for special scrutiny black males walking in these white neighborhoods ${ }^{\mathbf{1 4}}$ will themselves skirt black neighborhoods when walking after twilight. Taxi drivers refuse to stop for black passengers out of fear of being robbed. Before anyone responds with a defensive mountain of statistics, or with an orgy of self-criticism, it is important to pause and recognize racial stereotyping for what it is. Stereotyping rests on the process that cognitive psychologists call "categorization." We pick out what we hope are the most salient features of our world, and use them to organize and sort what we observe. When we stereotype, we generalize from our observations. This is a form of reasoning by induction, a capacity crucial to judgment, and indeed, to human existence. Aloysius eats a short-stemmed pink flower spotted with a spray of blue and falls ill. Bernadette eats a long-stemmed pink flower spotted

14. In Kolender v. Lawson, 461 U.S. 352 (1983), the Supreme Court rejected as unconstitutionally vague a California statute requiring those who wander and loiter to provide "credible and reliable" identification. Edward Lawson, whose fifteen arrests under the statute ultimately triggered Supreme Court review, is a six-foot tall black male who is, in his own words, "a walker by temperament." N.Y. Times, Dec. 5, 1983, § 2, at 14, col. 3 (reporting rejection of his subsequent damages claim against arresting officers). 
with a spray of blue and falls ill. Chumpney eats a long-stemmed white flower spotted with a spray of blue and falls ill. Dorcas hesitates before accepting the offer of any flower spotted with a spray of blue. She has placed all flowers with sprays of blue in a single category, and has stereotyped them as harmful. Without the ability to reason this way she might fall ill herself. She has done what we all do, used categorization to simplify her world. ${ }^{15}$

When the categorization treats skin color rather than leaf color as the relevant factor, social theorists call it "statistical discrimination," a rather benign term suggesting a kind of rational, race-specific sorting. Perhaps, as will be seen, racial categorization can be rational, but because it ties important decisions to the color of skin, "statistical discrimination" is too soft a phrase to describe it. Racial categorization presumes that skin color might itself have other than aesthetic import. This cognitive strategy, while not necessarily racist, nevertheless carries an element of risk. A better term for the strategy might be "racialism," because the word carries a reminder of the risk.

The tale of Dorcas and her flowers illustrates the danger associated with this type of decisionmaking. Dorcas, of course, is making what she considers a decision in her rational self-interest: She is protecting herself against poisoning. But Dorcas is also doing something else. After isolating the attribute that she considers most important--the spray of blue spots-she is reducing her fear of being poisoned by refusing flowers possessing that attribute. If it is possible to imagine flowers that want to be eaten, or at least that gain some benefit therefrom, Dorcas is in effect reducing the happiness of the blue-spotted flowers in order to increase her own. She is a potential victim of poisoning who, by working out the attribute that poisoned flowers have in common, has transferred some of the costs of her fear, her potential victimhood, onto the flowers. ${ }^{16} \mathrm{Her}$ own happiness is greater, because her fear is less; the happiness of the flowers is less, because their chances of consumption are smaller. The rationality of her choice is not at issue, and the conclusion that she has shifted some of the costs of her fear does not rest in any way on whether she is right or wrong in imagining that a spray of blue spots is the attribute that best predicts poison.

Some symbols are sufficiently blatant that they need no detailed expla-

15. The simplification occurs whether or not she has isolated the correct factor. She is economizing on information costs by avoiding a more detailed-and, perhaps, painful-study of each flower as it arrives. According to Richard Posner, "Discrimination so motivated is no different in its fundamental character . . . from a decision to stop buying Brand $\mathrm{X}$ toothpaste because of unhappy experience with a previous purchase of it, albeit the next experience with the brand might have been better." $R$. Posner, Economic ANalysis of Law 537 (2d ed. 1977). Professor (now Judge) Posner would make the same claim if Dorcas's sorting was along racial lines, although at that point the statement "no different" begins to sound a bit overstated.

16. She may also be losing a benefit: The flower she refuses may actually be safe and in addition quite tasty. 
nation, and the story of Dorcas and the poisoned flowers should be among them. Yet note that what Dorcas has done is not precisely what the public text of our national morality teaches that racists do. Dorcas has reasoned her way to her conclusion about the flowers, yet the popular image of racial stereotyping holds that an irrationally skewed reasoning process guides it. Gordon Allport, for example, in The Nature of Prejudice, insisted that racial prejudice is "an antipathy based upon a faulty and inflexible generalization."17 This argument suggests that the problem with racial stereotypes is overinclusivity, a judgment less normative than empirical. Racial stereotyping is bad, on this view, because it is irrational. The difficulty is that "Don't use them because they don't work" carries the same normative message as "Don't use them if they don't work." The implication is that there might lurk somewhere a set of better, more accurate stereotypes that should not be dismissed as involving "prejudice" because they are rational and thus, presumably, useful in ordering one's affairs. $^{18}$

It is dangerous to suggest that racial categorizations, even oppressive ones, might be acceptable as long as a case can be made for rational fit between ends and means. If the result of a categorization is oppressive, the reality of that result has little to do with the rationality of the racialist categorizations that might have been involved in bringing it about. In those areas that the law simply cannot reach to any practical effect-most areas of life traditionally, if suspiciously, considered private-virtually anyone who makes a judgment about another person that rests on race will believe the judgment to be a rational one.

The thoroughgoing functionalist would claim that the racial categorizations popular culture sometimes employs to help determine victimhood have obviously proved useful or they wouldn't be used. Individuals taking the contrary position might deny the rationality of the choice to use them, arguing instead (as Allport does) that those who indulge in racialist presuppositions are by hypothesis not acting rationally and consequently cannot be the judges of whether their categorizations are in fact useful. Like false consciousness theories and so many critiques of individual portraits of reality, however, this one threatens to devour itself in endless iteration.

The simplest moral choice might consequently seem to be a condemna-

17. G. Aliport, The Nature of Prejudice 9 (1955); see also Phelps, The Statistical Theory of Racism and Sexism, 62 AM. ECON. Rev. 659 (1972) (proposing statistical model in which high information costs produce discrimination).

18. This is similar to the assertion by some lawyer-economists that racial segregation is wrong in large part because it is inefficient. See, e.g., R. PosNer, THE Economics OF JuSTICE 354-55 (1981). Some theorist have recently suggested that statistical discrimination itself, rational or not, may also be inefficient. See Schuab, Is Statistical Discrimination Efficient?, 76 AM. EcoN. REv. 228 (1986); Lundberg \& Startz, Private Discrimination and Social Intervention in Competitive Labor Markets, 73 AM. Econ. Rev. 340 (1983). 
tion of all racial categorizations, which amounts in theory to a condemnation of racial awareness. Thus Brown v. Board of Education ${ }^{\mathbf{1 9}}$ was right-and racial segregation wrong-simply and solely because awareness of race is wrong. This condemnation sounds attractive as a vision toward which the nation should strive, until one pauses to consider its implicit denunciation of any awareness of the richness of America's racial and ethnic diversity. If there is no racial consciousness, then we cease to be a multiracial society. The intriguing magic of this view is the way that the criticism of the dominant construction of victimhood vanishes with a wave of the hand. Suddenly there are no forgotten victims who happen to be black because the concept of being black has no social or political significance.

This prospect is troubling to those who perceive as the products of the past the burdens resting on the shoulders of men and women of color, even after the worst forms of constituted racism have been swept away. It is morally repugnant, on this vision, that the costs of history should be left to lie on the victims and the inheritors of the victims. Those who have gained from racial oppression-by hypothesis, everyone not its victim-should carry a share of its costs. Racially conscious affirmative action programs are an example, but only the most obvious one, of the effort to transfer some of the costs of a legacy of oppression from those on whom they would otherwise fall. The argument for these programs supposes that only through use of racial criteria can those suffering from centuries of victimhood be properly identified. The additional burden that the programs place on white Americans-the lessened possibility of admission to law school, for example, or of obtaining the job of first choice-are seen as obligations of citizenship, like paying taxes. ${ }^{20}$

The immediately apparent practical difficulty with this approach is that there may be no logical stopping point. If white Americans must, as an obligation of citizenship, suffer a lessened possibility of admission to law school, should they perhaps also suffer a lessened possibility of sitting safely in a subway car? If the four youths shot down by Bernhard Goetz were in fact life's victims, did Mr. Goetz consequently have some responsibility to permit himself to be assaulted? More sophisticated versions of the theory have tried, without complete success, to offer the elusive stopping point that avoids this bizarre outcome. ${ }^{21}$ It is possible, in fact, that only the firmly entrenched bilateral individualist construction of reality

19. 347 U.S. 483 (1954).

20. See, e.g., Black, Civil Rights in Times of Economic Stress-Jurisprudential and Philosophic Aspects, 1976 U. IL.L. L.F. 559, 562.

21. In an analogous context, Laurence Tribe has suggested that the ideal theory of government responsibility is one that, upon hearing the question, "Why education and not golf?" permits the answer, "Because education is more important." Tribe, Unraveling National League of Cities: The New Federalism and Affirmative Rights to Essential Government Services, 90 HaRv. L. REv. 1065, $1066(1977)$. 
prevents pursuing to an analytic conclusion the bemusing possibility that white Americans have a responsibility to suffer passively the predations of violent (but oppressed) black criminals. ${ }^{22}$

Obviously, no one goes quite so far, but racially conscious remedial programs of the sort approved by the Supreme Court in Regents of the University of California v. Bakke $e^{23}$ are at least distant relatives, for they do, in effect, require some people who are white to stand passively as some people who are not slip past them. Critics argue that the programs perpetuate racism when they insist on racial criteria in the distribution of benefits and costs. ${ }^{24}$ This criticism, however, makes the peculiar assumption that racial consciousness and racism are the same phenomenon. If affirmative action programs are racially conscious, then they are by definition racialist. But although racialism may be an evil worth combatting, it is not the same evil as racism.

Every racial categorization makes a real difference to real people. Racism is the difference that the most oppressive racial categorizations make. The rationality or irrationality of a categorization has nothing to do with whether it is racially oppressive in practice. For example, the thesis that black people are born with a smaller endowment than white people of the qualities that influence intellect is obviously a racialist idea. It is also a racist idea, not because it is wrong and not because it is nonsense, but because of the difference that it makes. ${ }^{25}$

Racism has declared its presence in many millions of lives with stunning force and pervasiveness. Racism has an existential reality that has defied most attempts to discover its sources and explain its power. But whatever the source of racism, to count it the same as racialism, to say that two centuries of struggle for the most basic of civil rights have been mostly about freedom from racial categorization rather than freedom from racial oppression, is to trivialize the lives and deaths of those who have

22. There is an analogy but not an identity between this argument and the earlier debate over whether white Americans should sit by passively as newly enfranchised black Americans destroyed their culture. The arguments against passivity are as depressing as they are chilling. See, e.g., G. Frederickson, The Black Image in the White Mind (1971); J. Williamson, The Crucible OF RACE 109-223 (1984).

23. 438 U.S. 265 (1978).

24. See, e.g., A. BICKEL, The MoRality of Consent 133 (1975) (affirmative action programs make racism a matter of "whose ox is gored"); N. GLazER, AfFirmative Discrimination: ETHNic INEQUALITY AND PUBlic Policy 197 (1975) ("We have created two racial and ethnic classes in this country. . . . The two new classes are those groups that are entitied to statistical parity in certain key areas on the basis of race . . . and those groups that are not."); Van Alstyne, Rites of Passage: Race, the Supreme Court, and the Constitution, 46 U. CHI. L. REV. 775, 809 (1979) ("one gets beyond racism by getting beyond it now"). Supporters of the programs deny responsibility for perpetuating racism in American society, for as Randall Kennedy has pointed out, "[i]t is unrealistic to think . . . that affirmative action causes most white disparagement of the abilities of blacks." Kennedy, Persuasion and Distrust: A Comment on the Affirmative Action Debate, 99 HARv. L. Rev. 1327, 1331 (1986) (footnote omitted).

25. This is not to deny that the thesis is almost certainly nonsense. See generally $S$. Gould, ThE Mismeasure of MAN (1981) (debunking a variety of arguments supporting theory of innate intellectual inferiority of groups). 
suffered under racism. To pretend, as, for example, top officials of the Reagan Administration have, that the issue presented in Bakke was the same as the issue in Brown is to pretend that history never happened and that the present doesn't exist. ${ }^{28}$

The critics of affirmative action, however, may simply correct their semantics, to charge now that the programs perpetuate racial stereotyping-racialism, not racism. Advocates of racially conscious programs usually respond by offering a less-than-compelling distinction between stereotypes that are benign and stereotypes that are malign. ${ }^{27}$ The distinction is a neat one, and it might even work if the question involves distinguishing laws that affirmatively integrate and laws that affirmatively segregate. "Our purpose," the affirmative action advocate might say to the avowed segregationist, "is holier than your purpose." This argument harks back to Allport's definition, for the racial categorizations are distinguished according to their relative efficacy in meeting the societal goal of equality; in other words, what matters is rational relation to the holy purpose. But once the critic of affirmative action abandons the argument that Bakke is Brown, the distinction is no longer relevant, for the foe is not the effect of the categorization, but the categorization itself.

This is a turn that matters, for millions of tiny, individual, racialist decisions are made each day, and are justified, in the minds of most of the decisionmakers, not on the ground that they oppress, but on the ground that they are rational. Once it is accepted that race can carry significance-a point which is central to the case for racial consciousness in remedial programs-the dispute may be reduced to one over what race more rationally signifies: an educational disadvantage that a just society will find ways to overcome, or a tendency toward criminality that a just society will avoid. The fact that one of the two choices seems morally odious does not mean that no one could rationally conclude that it is correct. The societal goal of preventing violent crime seems just as worthy as the societal goal of eliminating the legacy of racial oppression. If the tools of racial categorization can fairly be used for the second, it is no easy matter to explain, to someone who believes them helpful, why they cannot be used for the first. If all one can say is, "You've got the statistics wrong," then the degree of moral suasion is very slight. ${ }^{28}$ Thus the critic of affirmative

26. Cf. Meese, The Battle for the Constitution, PoL. REv., Winter 1986, at 35 (equating battle against racial preferences with battle against racial segregation); address by Assistant Attorney General William Bradford Reynolds, Earl F. Nelson Memorial Lecture, University of Missouri School of Law (Sept. 12, 1986) (sounding similar theme).

27. See, e.g., Fiss, Groups and the Equal Protection Clause, 5 PhIL. \& Pub. AfF. 107, 155-57 (1976); Wright, Color-Blind Theories and Color-Conscious Remedies, 47 U. CHI. L. REv. 213, 220-21 (1980).

28. The degree of rational suasion might also be small, because people are quite capable of shutting out facts that interfere with their predetermined views of the world. This proposition poses problems for theories of law based on the supposition that people react rationally to fresh information. For sensitive analyses of some of the problems posed by human irrationality, see Akerlof \& Dickens, 
action programs is able to concede that racism is a greater enemy than racialism, and yet point as well to the risks involved in perpetuating racialism. A society without racism is an excellent goal, the argument might conclude; teaching that racial consciousness is wrong is a vital step along the way.

The bilateral individualist construction of victimhood that is embedded so powerfully in American culture provides a second string for the antiaffirmative action bow. According to the dominant construction of victimhood, the only justifiable shift of costs is one that requires the individual transgressor to make compensation for an individual transgression. Only those who deny another individual employment or a home or a place in college ought to bear the burden, and the burden is only the cost of the single racist transgression. The theory denies that all black people are "victims" in any legally or morally cognizable sense. Whether or not there are any present day legacies of racism past, the bilateral individualist construction of victimhood denies that anyone holds a legal responsibility to alleviate them. A victim is someone injured by someone else, and only the someone else, not the society as a whole, deserves punishment. If the someone else did something to the would-be victim's great-grandfather, no current moral responsibility exists.

Yet at the same time that the dominant culture resists the notion that black people as a group might be victims, it often seems quite comfortable in concluding that white males as a group are victimized by racially conscious affirmative action programs. They are victims, however, not in the bilateral individualist sense of being harmed directly by transgressors, but in the sense that their destiny is controlled by non-bilateral-individualist programs. They are victims in the same way that people whose marginal tax rates are high are victims: They are being made to pay the costs of wrongs they did not cause. The possibility that black people as a group might be victims in precisely the same sense is one that the culture generally chooses to resist. A principled distinction is certainly available: The particular white males who are harmed by affirmative action programs may be difficult to identify, but their harm is clearly traceable to a present-day transgression. So if the dominant bilateral individualist construction of victimhood commands an end to racial preferences as compensation for historical victimhood, the political culture that reflects that command can hardly be faulted for its philosophical consistency.

And yet many members of the same public that rejects programmatic cost shifting practice instead an unprogrammed version, one in which costs are spread beyond individual transgressors to potential transgressors who happen to be black. Thus there is the taxi driver, robbed by a passenger

The Economic Consequences of Cognitive Dissonance, 72 AM. Econ. REv. 307 (1982); Sunstein, Legal Interference with Private Preferences, 53 U. CHI. L. REv. 1129 (1986). 
who is black, who refuses to stop for the next potential rider whose skin is the same memorable color; the shopkeeper in New York City, cautious with her wares, who locks her door to the public and refuses to admit would-be patrons with skin colors associated with criminality; and even the radio journalist, who apparently felt it vital to call to her audience's attention what she believed Bernhard Goetz must have known (and, by implication, must have acted on)-and what Mr. Goetz's critics, in her view, ignore-that the number of assaults committed in New York by criminals who happen to be black is far greater than extrapolation from the percentage of New Yorkers who are black would predict.

There is sound here, fury too, but it is important not to misinterpret what they signify. What is at work is not necessarily racism, in the sense of a conscious victimization based on skin color, but racialism, the awareness of skin color and the belief that it can have other than aesthetic import. The taxi driver and the shopkeeper are desperately casting about for a way of avoiding victimhood; and just as Dorcas realized that the poisoned flowers shared a spray of blue spots, they hit upon the notion that many criminals have the same skin color. Possibly in the racially unconscious utopia urged by critics of racial preferences, the notion that skin color might be a predictor of criminal tendency would never have occurred to either taxi driver or shopkeeper, because it would never occur to them that skin color might correlate with anything. In a racially conscious society, however-in a world in which color makes a difference-their conclusions are probably inevitable.

Is any of this the fault of remedial programs that take explicit note of race and give it significance? Possibly not, and yet the supporter of the programs does carry a special burden-the burden of developing a consciousness, a mode of dialogue, in which affirmative action programs can evolve in a way that prevents the evolution of the analogous generalizations that lead fearful shopkeepers to lock their doors to customers who happen to be black. ${ }^{29}$ It may seem odd to place this burden on the people who are trying to remedy the effects of the nation's legacy of racial oppression, when it is the taxi drivers and shopkeepers who, through racialist categorizations, alleviate their own fear of victimization by turning law-abiding black people into victims of that fear. But even though affirmative action's supporters are at best relatively insignificant purveyors of racialist thought in America, the criticism is still on the mark: The programs $d o$ rely on racialist categorization, and thus $d o$ work to perpetuate the idea that skin color carries significance. In a society striving for racial unconsciousness, the shopkeeper still might shut her door; but the popular culture could then simply say to her that shutting a door for racialist reasons is wrong because all racial categorizations are wrong. The

29. See Days, Fullilove, 96 Yale L.J. 453, 457 (1987). 
supporter of some but not all racial consciousness, however, currently has no mode of dialogue adequate to explain why other people's racialist categorizations are acceptable when thought to be rational while the shopkeeper's, even if rational, are unacceptable. ${ }^{30}$

Still, the dominant culture cannot escape the greater share of responsibility for the shopkeeper's choice-or the choice of Bernhard Goetz's admirers-to choose as their victims people whose skins are black. Personal choices-choices made every day on where to live and whom to love-are often racialist in character. These personal choices, in turn, shape what happens to others who are racially identifiable. They serve as the link between racialism and racism. An example of the link is implicit in Gary Becker's argument that racial discrimination in the market reflects preferences by individuals of one color not to associate with individuals of another. ${ }^{31}$ This is a sensible although modest tale to tell about how racialist personal choices affect real people who have no real choice. The racism is the oppressive difference that one group's racialist choices make in the lives of the other.

Perhaps we should simply accept the existence of racism as an inevitable presence, ugly and brooding and terribly sure, that will live in our public life as long as racialist choices live in private. After all, a functioning majoritarian representative democracy assumes that within those areas where collective decision is the rule, each person's vote carries the same weight. Although such a system aggregates private preferences only imperfectly, it does tend over time to produce law reflecting at least those preferences that are deeply felt and widely held. A society in which people make many small, individual racialist choices is a society in which, over time, government will be pressed to adopt policies consistent with this racialism. The policies adopted need not be racially specific to be consistent with the racialist suppositions of the voters. If government policy is shaped by the unacknowledged racial categorizations inculcated and acted on in daily life, the risk is substantial that government policy reflecting racialist preferences will, in the end, prove racially oppressive. ${ }^{32}$

A society that recognizes its own racialist character might try to avoid some of these harmful effects by adopting special decision rules that place certain subjects beyond the will of a majority of the popular representatives. This, in fact, is what America has tried to do. But if millions of

30. For an effort to provide such an explanation from a perspective that styles itself as vutside of the mainstream, see Matsuda, Looking to the Bottom: Critical Legal Studies and Reparations, 22 HARV, C.R.-C.L. L. REV. 323 (1987).

31. See G. Becker, The Economics of Discrimination 101-52 (2d ed. 1971) (presenting model of racial discrimination in markets).

32. For a fascinating investigation of the concepts the legal system currently uses to cope with generalizations of this kind when the stereotyper is unaware of the racial nature of the reasoning process, see Lawrence, The Id, the Ego, and Equal Protection: Reckoning with Unconscious Racism, 39 Stan. L. Rfv. 317 (1987). 
voters routinely make personal choices that reflect a consciousness of race and a willingness to use it in the categorization process necessary to daily existence, government policies that respond to those individual decisions will not be avoided by, for example, prohibiting talk about race. Voters will prefer a world that reflects their own world views, and will seek, even when race-talk is forbidden, those candidates and those initiatives that in some way reflect their own racialist generalizations. An election campaign or a legislative battle in which race is not openly an issue may nevertheless involve racialist choices by the electorate or by its legislators.

None of this is new. The evolution of the law of equal protection in recent decades has involved the development of increasingly precise decision rules for ferreting out the most egregious examples of racialism in the making of public policy. In the days of Brown v. Board of Education, the beast was relatively easy to find. In the 1970's, concerned that the hunters were spreading their nets too widely, the Supreme Court ruled that the equal protection clause forbids only consciously racist policy. ${ }^{33}$ But an openly racist legislative consciousness is potentially quite beside the point. And even were it a more sensible starting point than it is, a prohibition only on openly racialist choices to oppress provides no relief to the victims of the nation's historical legacy of racial oppression. It is something of a tragic puzzle to try to understand the suspicion with which the culture so often views the possibility of the continuing victimhood of the statistical mass of black Americans, whose relative disadvantage is easy to see. It is no easy matter to make a plausible case that none of the disadvantages suffered by black people as a group can be traced to the legacy of slavery and segregation on which the supporters of affirmative action rest their case. Yet to concede that the nation's legacy of racism has any lingering effects is to concede the continuing victimhood of black people generally. The principal alternative is to suggest what emergent popular morality condemns: that the inferior position of black people is linked to the natural inferiority of black people.

The dominant culture refuses to choose between these alternatives. It neither recognizes victimhood in the obviously inferior social and economic position of disproportionate numbers of black people nor states that the position of black people is the fault of black people. At the same time, the political leadership of the same culture is capable of an awesome aggressiveness when it asserts the victimhood of an amorphous mass of white males, whose relative disadvantage, although theoretically quite palpable, is not so easy to grasp. Were one to force the culture to speak in its chosen language of bilateral individualism, the message would come down to this: In contemporary America, the victims of racialist government programs

33. See Village of Arlington Heights v. Metropolitan Hous. Dev. Corp., 429 U.S. 252, 265 (1977); Washington v. Davis, 426 U.S. 229, 245 (1976). 
happen to be white. Every act of victimization requires a transgressor, and for the white male victims of racially conscious affirmative action, the political leadership tracks down the transgressors with alacrity. And who do the transgressors turn out to be? Why, the "less qualified" individuals who have taken the spaces rightly belonging to the excluded white males. In the upside-down world of bilateral individualism the transgressors are victims who happen to be black.

III.

Much of the American legal system rests on the identification of victims. Every crime, every tort, every violation of fundamental right is an act done not just by someone but to someone. Outside of a small and controversial universe of crimes that are called "victimless," if there is no victim, there is no offense. This assertion is a commonplace, not only of American law, but of modern liberal democratic thought. And yet, as worked out in practice in a society where racial categorizations are commonplace, this simple principle produces troubling results.

The law in its majestic neutrality takes no official note of the race of the victim unless the victim places race in issue, as for example in a claim of racial discrimination. Even when the victim's race matters, members of one race are formally entitled to the same constitutional and legal protections as members of another. As the courts have insisted again and again over the past century, antidiscrimination laws protect everyone against discrimination on the basis of race. ${ }^{34}$ The constitutional command of equal protection of the laws can hardly be taken to mean anything else.

Just as antidiscrimination law, created originally as a vehicle to secure the equality of black people, is to be applied without regard to race, the criminal law supposedly cares only about the conduct of the accused, not his skin color. The history of American criminal law is of course quite to the contrary; the use of the criminal sanction as a tool of racial oppression has been so ubiquitous in American experience as to require no citation. In recent decades, the battle against oppression has had its successes in the field of criminal law. In one sense-the important sense of public dialogue-the tide has plainly turned. Many people may suppose (wrongly, as it happens) that most crimes in urban areas are committed by perpetrators who happen to be black, ${ }^{35}$ but those few who insist on the point in letters to the editor are treated as oddballs.

Yet our public insistence that race be divorced from debate over crime does not match the activities of our institutions. At the level of private

34. See, e.g., McDonald v. Santa Fe Trail Transp., 427 U.S. 273, 278-79 (1976); Strauder v. West Virginia, 100 U.S. 303, 307 (1880) (dicta).

35. According to the New York Transit Authority, however, the great majority of reported robberies that occur on the New York subway system are committed by black offenders. Press, Hackett, Johnson \& Anello, A Trial That Wouldn't End, NewsweEk, June 29, 1987, at 21. 
fears, private prejudices, private categorizations, the link between race and crime is an intimate one. Although the law might be structured to try to correct these private racial categorizations through its teaching authority, it can take no official note of them when they do not burst into the public arena, as, for example, through a racial assault by an angry white mob. Private prejudices are private; they fall into the realm of conscience, the realm that, according to the often extravagant arguments of the liberal tradition, must be entirely free from official interference. ${ }^{36}$ But a theory that works so hard to protect primacy of individual conscience carries the risk of leakage from private conscience into public activity. When the public activity involves a racist mob, the legal system can recognize and deal with the problem (although the legal problem is said to be the assault, not the racism that provoked it) but when the public activity lacks overtly racist character, when private prejudices leak into public institutions in ways that do not involve direct action or official articulation, traditional legal institutions are at a loss. Sometimes, although the leakage has its victims, the victimization is sufficiently subtle that a court can scarcely be blamed for failing to notice it. And sometimes the victimization is so pervasive that there is nothing to be done about it.

An ironic illustration of both propositions is the Supreme Court's decision late last Term in McCleskey v. Kemp, ${ }^{37}$ which in its peculiar way-but not the way that its most vociferous critics insist-stands as a stark statement of the way that the race of the victim still matters. Warren McGleskey, a black man sentenced to die in Georgia's electric chair for the murder of a police officer in the course of an armed robbery, presented the Court with evidence raising a strong inference that prosecutors, in determining whether to seek death sentences, and juries, in deciding whether to impose them, are influenced by the race of the victim. The evidence Mr. McCleskey offered was drawn from two careful analyses of capital sentencing practices in Georgia, generally referred to as "the Baldus study" after David G. Baldus, the principal author. The Baldus study demonstrates that those who have killed white people have received the death penalty in Georgia at many times the rate of those whose victims happen to be black. ${ }^{38}$

36. For a general discussion of the primacy of conscience in liberal theory, see D. RICHARDS, Toleration and THE CONSTITUTION (1986).

37. 107 S. Ct. 1756 (1987).

38. "The raw numbers collected by Professor Baldus indicate that defendants charged with killing white persons received the death penalty in $11 \%$ of the cases, but defendants charged with killing blacks received the death penalty in only $1 \%$ of the cases." $I d$. at 1763 . Baldus found that the death penalty was assessed in $22 \%$ of the cases involving black defendants and white victims; $8 \%$ of the cases involving white defendants and white victims; $1 \%$ of the cases involving black defendants and black victims; and $3 \%$ of the cases involving white defendants and black victims. Id.

In their published work, Professor Baldus and his coauthors have emphasized the tentative nature of their conclusions. See, e.g., Baldus, Pulaski, \& Woodworth, Arbitrariness and Discrimination in the Administration of the Death Penalty: A Challenge to State Supreme Courts, 15 STETSON L. REv. 
The Court's response to the detailed evidence set forth in support of Mr. McCleskey's claim that his sentence violated the Eighth Amendment and Equal Protection Clause was a labored "So what?" The data, the Justices explained, were not as troubling as they might seem. As the Court delicately put the matter, "At most, the Baldus study demonstrates a discrepancy that appears to correlate with race." ${ }^{39}$ But the reality, not the appearance, mattered: "Apparent disparities in sentencing are an inevitable part of our criminal justice system."40 The Baldus study, however, suggests more than a random "disparity" or a mere "discrepancy;" it suggests that jurors are influenced by color, probably the color of the defendant, and almost certainly the color of the victim. For the Justices in the majority, "almost certainly" was not enough: "Where the discretion that is fundamental to our criminal process is involved, we decline to assume that what is unexplained is invidious." 11 The Baldus study, the Court concluded, "does not demonstrate a constitutionally significant risk of racial bias" in the determination of whom the state will kill.42

If, as Charles Black once suggested, the sovereign prerogative of the philosopher is laughter, then the sovereign prerogative of the pragmatist must be tears, for there is a tragic inevitability in the Court's conclusion. The result could hardly have been a surprise to black Americans who know, in the way that they know their own names, that the criminal justice system is not the same for them as it is for others. Typically, when the Court hands down a decision so steeped in the rhetoric of doubting the evidence, the Justices are accused of ignoring the nation's history of racial oppression. This, for example, was the charge leveled when the Justices ruled a few years ago in Memphis $v$. Greene ${ }^{43}$ that the city could close a street used by black drivers to get downtown quickly, leaving it to be used only by residents of an all-white neighborhood who demanded the closing. But in retrospect, the proper diagnosis in such cases as these is not amnesia but agnosia; the problem is not an inability to remember the past, but an incapacity to integrate the present. The difficulty confronting both Mr. McCleskey and Mr. Greene was neither history (as the Court's critics would have it) nor happenstance (the Court's own response); the problem

133, 165 (1986) ("it appears that illegitimate factors, especially the race of the victim, may influence many of the sentences imposed") (emphasis added); Baldus, Pulaski, \& Woodworth, Comparative Review of Death Sentences: An Empirical Study of the Georgia Experience, 74 J. CRIM. L. \& CRIMINOLOGY 661, 709-10 (1983) ("our data strongly suggests [sic] that Georgia is operating a dual system, based on the race of the victim, for processing homicide cases") (ermphasis added). Curicusly, the scholars, with no obligation to draw a conclusion from their data, felt compelled to point out what the data seemed to show, whereas the Court, upon whom a duty to decide is incumbent, was content to leave the data as an essentially uninteresting mystery. See infra text accompanying note 41.

39. $107 \mathrm{~S}$. Ct. at 1777.

40. Id.

41. Id. at 1778 .

42. Id.

43. 451 U.S. 100 (1981). 
was, as it is and presumably will be for the near term, the private racialist analyses of individuals transformed into unconsciously oppressive public policies.

It is unlikely that members of the jury that sentenced Mr. McCleskey got together and said to one another, "Well, his victim was white, so he burns." It is unlikely that the residents of Hein Park, the white neighborhood involved in Memphis v. Greene, went door to door with the message, "Sign here to keep the niggers out." But the jury and the residents, like hundreds of juries and millions of residents, were quite likely guided by the unconscious racialism that pervades and perverts so much thought, so much talk, so much action. The individual members of the jury and the individual residents of Hein Park are therefore not culpable in the bilateral individualist way, and yet have their victims all the same; and the victims, once more, happen to be black.

Convicted murderer Warren McCleskey might seem an unlikely candidate for victimhood. The Justices in the majority plainly realized this when they easily spotted the biggest hole in Mr. McGleskey's claim, a hole more psychological than legal-logical, because it is a hole in the facts, not in the law: Say what one will about racism or racialism, Mr. McGleskey was sentenced to die for shooting a police officer while robbing a store. No matter what the race of the killer, no matter what the race of the victim, anyone who accepts in general terms the constitutional validity of capital punishment would certainly agree that a state possesses authority to impose this punishment on those who kill its peace officers. Once one concedes that some people deserve to die, it is quite difficult to build a wall between Warren McCleskey and all the others. This the majority acknowledged when it dismissed, at the very end of its opinion, his "wide ranging arguments that basically challenge the validity of capital punishment in our multi-racial society."

The majority's analysis, although adequate to its own point, entirely misses the more fundamental challenge posed to the criminal justice system by the Baldus study-for Warren McGleskey is not the relevant victim in the case that bears his name. To understand who the victims are whose plight the jury reinforced and the Court ignored, it is worth pausing to consider the possibility that the decision in McCleskey $v$. Kemp is starker than the Goetz trial just as the decision in Korematsu v. United States $^{45}$ was starker than the forced resettlement of Japanese-Americans that it approved. A jury may state a community's outrage, a President may act out a community's fear, but the Supreme Court of the United States is supposed to guard constitutional values in the worst of times; a Constitution that cannot be defended from the passion of the mob is not

44. 107 S. Ct. at 1781 .

45. 323 U.S. 214 (1944). 
fundamental law. When the Supreme Court places its imprimatur upon a horror, as it did in Korematsu, the horror becomes a constitutional tragedy, not merely a political one. ${ }^{18}$

In one sense to compare Korematsu to McCleskey is to insult the patriotic Americans whom the Court permitted the military to incarcerate. But the difference is lessened if McCleskey is given a closer look. The significant problem with McCleskey $v$. Kemp is not, as its critics contend, that the Court rejected the claim pressed by Warren McCleskey himself. The problem is that the majority wrote in a way that made it possible to evade a more fundamental difficulty raised by the Baldus study-that racialism might be responsible not only for the disproportionate execution of murderers who happen to be black, but for inadequate protection of murder victims who happen to be black.

Mr. McCleskey was to be executed by the state. But most of the thousands of people who die in this country each year by someone's volitional act are killed not by the state but by other individuals. These murderers are, according to the McCleskey majority, subject to the laws of the state and the discretion of the jury. This is bilateral individualism in its purest form: The guilty must be punished! The citizens of the state can provide the possibility of capital punishment. A jury drawn from those citizens can decide whether the punishment is appropriate in particular cases. As the Court explained, "the inherent lack of predictability of jury decisions does not justify their condemnation. On the contrary, it is the jury's function to make the difficult and uniquely human judgments that defy codification and that 'buil[d] discretion, equity, and flexibility into a legal system." "\$47

Well, of course! The jury brings with it a range of preconceptions, and if racialist categorizations are widespread in society then racialist preconceptions would be among the factors shaping the "discretion, equity, and flexibility" that the McCleskey Court extolled. Justice Powell, who authored the majority opinion, rejected Mr. McGleskey's reliance on the Baldus study in words so carefully chosen that he must at least have suspected the presence of racialist preconceptions. The question, he explained, was not whether there was "some risk of racial prejudice influencing a jury's decision." 48 The question was, rather, "at what point that risk becomes constitutionally unacceptable." ${ }^{\prime 4}$ Some risk of racial categori-

46. See Rostow, The Japanese-American Cases-A Disaster, 54 YALE L.J. 489, 491 (1945) (Court's action "converts a piece of war-time folly into political doctrine, and a permanent part of the law"); see also Korematsu v. United States, 323 U.S. 214, 246 (Jackson, J., dissenting) ("A military commander may overstep the bounds of constitutionality, and it is ancident. But if we review and approve, that passing incident becomes the doctrine of the Constitution.").

47. $107 \mathrm{~S}$. Ct. at 1777 (quoting H. Kalven \& H. Zeisel, The American Jury 498 (1966)).

48. Id. at 1775 .

49. Id. (quoting Turner v. Murray, 106 S. Ct. 1683, 1688 n.8 (1986)). In Turner v. Murray, a sharply divided Supreme Court overturned the death sentence of a black man whose victim was white because the judge denied a request from defense counsel that potential jurors be questioned about 
zation, in other words, is probably inevitable and even constitutionally permissible. But there is no need to acknowledge a constitutionally acceptable risk of racialism among jurors unless racialist preconceptions are widespread. Once one concedes the ubiquitousness of racial categorizations, it is insupportable to pretend that all of them, or perhaps even many of them, are benign.

Justice Powell was equally cautious in choosing the terms in which he rejected the study itself. The study, he wrote, "does not demonstrate a constitutionally significant risk of racial bias affecting the Georgia capitalsentencing process." 50 No racial bias, he concluded; nothing about racial consciousness. A rational generalization, perhaps he meant to say, is not a bias; it is simply one in a complex set of preconceptions that jurors bring with them into the jury box-preconceptions, according to the Court, that the jury system is supposed to bring to bear on criminal cases. ${ }^{51}$ Even if one accepts the dubious distinction between bias and preconception, the stark facts unearthed by Professor Baldus show the consequence of those preconceptions. A black defendant whose victim is white is twenty-two times more likely to receive the death penalty than is a black defendant whose victim happens to share his race. ${ }^{52}$ This might indeed be a problem for the black murderer, but that possibility pales beside what should be obvious: the massive discrimination against black victims.

The discrimination is evident no matter what argument one chooses as justification for capital punishment. One might, for example, justify the death penalty as a deterrent, arguing that its use in particular circumstances will inhibit others who might repeat them. Or one might justify the death penalty as retribution, involving a statement of the society's outrage at the crime for which the penalty is imposed. On either model, the juries that over time punish black people who kill white people far more harshly than black people who kill black people are making statements about the value of black lives. When black people kill white people, something has occurred that must be deterred, something has happened that must be condemned. When black people kill each other, however, deterrence is ignored and retribution is forgotten. When flexible juries use their discretion to impose the ultimate penalty, the lives of victims who happen to be black are simply worth less.

That, in fine, is what the Baldus study teaches, and the lesson is indeed a stark one-too stark for the majority, and apparently too stark for the dissenters, who only hinted at the possibility that the true victims of the

\footnotetext{
their own racial prejudices. Justice White's plurality opinion pointed out that "[b]ecause of the range of discretion entrusted to a jury in a capital sentencing hearing, there is a unique opportunity for racial prejudice to operate but remain undetected." $106 \mathrm{~S}$. Ct. at 1687.

50. $107 \mathrm{~S}$. Ct. at 1778.

51. See id. at 1775-77.

52. See supra note 38 . The Justices in the majority made no serious effort to dispute the methodology of the Baldus study.
} 
Georgia capital sentencing system are not the black people among those who are sentenced but the black people among those the criminal law is supposed to protect. ${ }^{53}$ It is easy to see why the lesson is too stark to be acknowledged, for it suggests once more the difference that racialist categorizations can make in the lives of real people. When the difference is oppressive, it is racist, and the study's bottom line is that racist policy has been made, and continues to be made, as the result of probably unconscious racialist categorizations about the relative values attached to the lives of people of different skin colors.

If racialism leads to racist policy in this tiny corner of the criminal justice system, how much more might there be in all the other nooks and crannies that the courts repeatedly explore? The majority noted that studies have pointed to discrepancies in sentencing based on many different factors, ${ }^{54}$ and even if one accepts the dissenters' angry correction that only one of these factors-race-carries constitutional significance, ${ }^{55}$ the Court's dilemma is roughly the same. Capital crimes are not the only ones in which the race of the victim appears to carry significance, and it is potentially quite bewildering to try to imagine what a court of law could possibly do with a claim that the criminal law is not applied in a way offering potential victims of a particular color adequate protection, or, for that matter, just who the proper plaintiff would be. A good argument can be made that Mr. McCleskey should not be the one to complain, but if not he, then who? A citizen who feels unprotected? ${ }^{56}$ The survivors of a black murder victim? In what forum? And what would the relief be? An injunction against enforcement of the death penalty (or, potentially, any criminal penalty) until such time as statistics demonstrate-

But in a society where racialist categorizations survive, there is no sensible way to finish the sentence. People will bring preconceptions to the jury box as long as preconceptions exist. And if over time the discrepan-

53. Justice Brennan, for example, recited the figures on the race of the victim but concluded, somewhat awkwardly, that the figures documented "the risk that McCleskey's sentence was influenced by racial considerations." $107 \mathrm{~S}$. Ct. at 1785 . The conclusion is of course correct; what remained was to remind the reader of just whose race it was that influenced the sentencing juries. Justice Stevens referred to the process revealed by the study as "a racially discriminatory death penalty." Id. at 1806. He, too, was essentially correct; but at the same time, he failed to mention that the evidence of discrimination based on the race of victims showed sentencing disparities significantly larger than did the evidence of discrimination based on the race of perpetrators.

54. Id. at $1779-80 \&$ nn.39-44.

55. See id. at 1792 (Brennan, J., dissenting) ("[T]o reject McCleskey's powerful evidence on this basis is to ignore . . . the particular repugnance of racial discrimination.").

56. The Supreme Court has denied standing to citizens desiring to challenge state underenforcement of the criminal law. See Linda R.S. v. Richard D., 410 U.S. 614 (1973). But as Frank Easterbrook has pointed out, "[I]t is hard to take seriously the claim that enforcement of legal rules does not affect bystanders. The rule against murder is designed to prevent other people from slaying me, as well as others, and I suffer an injury if the police announce that they will no longer enforce that rule in my neighborhood. . . . Only a judge who secretly believes that the law does not influence behavior would find no injury in fact." Easterbrook, The Supreme Court, 1983 Term-Foreword: The Court and the Economic System, 98 HARv. L. REv. 4, 40 (1984). 
cies become apparent, and no explanation other than the existence of racial preconceptions in sentencing behavior can explain them, what could a court concerned about adequate protection of black victims finally do? Obviously, it might order all of those whose victims happen to be white released, although the political impracticality of the action makes it unlikely, and besides, the argument that those who would be released do not belong in jail has little moral or logical appeal. Moreover, a court that insisted that racialist preconceptions pervade the criminal justice system would risk ridicule, even defiance, certainly diminution; for the court, in universalizing the notion of racialism, would be removing the prop of indignation which lends popular support to judicial battles against racism only as long as the court preserves the popular image, in which the racist is always somebody else.

Judicial decision is too crude a screen to filter out all leakage from private conscience into public action. ${ }^{67}$ Only a change in popular consciousness can do that, and absent that change, the majority's decision was right, but not for the reasons the Justices thought. The problem has nothing to do with the heinousness of Mr. McCleskey's offense or with the right of the people of a state to choose the criminal sanction they prefer. The problem is one of fairness to victims, and it is one for which constitutional adjudication using existing doctrinal tools offers no remedy. ${ }^{58}$

The slippery slope does lie ahead, and the McCleskey case, had it gone the other way, would have taken all of us right to the brink. For if the victims or potential victims of crime can challenge statutes said to be executed in ways that protect them inadequately by imposing too small a penalty, there might well be no stopping point; the criminal law and its pretensions of racial neutrality would be out the window-a result that the constituted authority of the society would never abide. No wonder nine Justices tiptoed around the matter: Sometimes the exposure of the pervasiveness of racialism, and of the racist policy it entails, can cost too much. Better to pretend that the jury behavior reflected by the Baldus study is simply "unexplained," to preserve the image of the dispassionate

57. In a paper unavailable when this essay was written, Randall Kennedy has argued that the majority's preferred test for uncovering racial discrimination-a test that the Baldus Study, so the Court held, failed to satisfy- "is hopelessly inadequate as a tool for responding to racial oppression in its modern guises." Adds Professor Kennedy: "By conditioning the availability of a remedy under the Fourteenth Amendment on proof that a decisionmaker is out to get blacks because of their racial identity, Justice Powell and his colleagues display minds trapped by vision of old conquests-the battle against de jure segregation." This vision, he warns, "ignores the chameleonlike ability of prejudice to adapt unobtrusively to new surroundings and, further, to hide itself even from those securely within its grip.” Kennedy, McCleskey v. Kemp: Race, Death and the Supreme Court, 87-88 (1987) (unpublished manuscript).

58. Several of my colleagues independently suggested a legislative remedy: If the criminal law is underenforced against transgressors whose victims are black, then the deterrence theory implies that the penalty for victimizing black people should be greater than the penalty for victimizing others. This of course is reverse discrimination with a vengeance, and would in any case be unavailable if the underenforcement comes in cases in which the maximum penalty is already death. 
jury, together with the implicit conclusion that the disproportionate sentences are a coincidence.

That part of the public that lionized Bernhard Goetz would have little option but to agree, and to mute any discussion of the contradiction between its attitude here and its reaction to the Goetz case, where it offered such solid support to the victim who claimed that the criminal justice system protected him inadequately. It is one thing to root for Mr. Goetz, shooting on the subway, for the transgressors can be identified readily, and their victim is simply meting out well-deserved punishment. It goes quite a bit too far in the other direction to complain that black victims or potential victims of crime are valued less than white ones, for the transgressors are difficult to identify and impossible to punish. Better to say, with heavy sadness, "We may not always punish evenly, but punish we must, if the social contract is to survive."

But if the Baldus study is to be treated as evidence of no more than coincidence, then the factors that must coincide are these: When black people who have killed white people come before juries for sentencing it just so happens that their offenses are so serious that the state must take their lives; when black people who have killed black people come before juries it just so happens, in case after case, that their offenses turn out not to be as serious. If one can accept all of this as coincidence, as random, as not linked to race, then McCleskey $v$. Kemp ought not to be a troubling case.

If on the other hand one finds this chain of coincidences unlikely, a more tragic explanation is available. According to Simone de Beauvoir, in a culture dominated by men, people come in only two varieties-women and human beings. When women insist on their right to be human beings, she explains, they are accused of wanting to be men. All too often, American legal and political culture seems to suggest the grimly analogous principle that there are two varieties of people who are involved in criminal activity, black people and victims. So perhaps when victims happen to be black, the culture rationalizes the seeming contradiction by denying that there has been a crime. 